\title{
A Liquefaction Resistance of Sand-Fine Mixtures: Short Review with Current Research on Factors Influencing Liquefaction Resistance
}

\author{
Bakhtiar Affandy Othman ${ }^{1^{*}}$, Aminaton Marto ${ }^{1,2}$ \\ ${ }^{1}$ Disaster Preparedness and Prevention Centre, Malaysia-Japan International Institute of Technology, Universiti \\ Teknologi Malaysia, 54100 Kuala Lumpur, MALAYSIA \\ ${ }^{2}$ Associate Fellow, Centre of Tropical Geoengineering (GEOTROPIK), Faculty of Civil Engineering, Universiti \\ Teknologi Malaysia, 81310 UTM Skudai, Johor, MALAYSIA \\ *Corresponding author
}

DOI: https://doi.org/10.30880/ijie.2019.11.07.004

Received 30 May 2019; Accepted 30 July 2019; Available online 10 August 2019

\begin{abstract}
Sand is well understood as susceptible material to liquefy under seismic condition. In many cases of liquefaction, the loss of property and damages occurred due to the earthquake phenomenon are caused by sandy soils. Thus, many laboratory experiments and field tests on soil liquefaction engineering have been mandatorily focusing on the liquefaction resistance of sand-fine mixtures. The interaction between sand and fines particles appears to be well studied subject. However, there are some contradictory findings on some factors influencing liquefaction resistance in sand-fine mixtures. Therefore, this paper aim to present results and current findings from previous researchers which focused on sand-fine mixtures using various type of sand to interpret liquefaction resistance and its behaviour. In addition, microstructure test needs to be conducted for verification and analysis of the results on grading and particle sizes characteristics. It has been identified that recent findings on the particle size distribution and grading characteristics of sand in sand-fine mixtures are still contradicting. It has also been found that there are no study using different types of sand to reconstitute tropical sand-fine mixtures; and limited study focused on the coefficient uniformity, $\mathrm{C}_{\mathrm{U}}$ and coefficient of curvature, $\mathrm{C}_{\mathrm{C}}$ on liquefaction resistance relationship.
\end{abstract}

Keywords: Liquefaction resistance, sand-fine mixtures, grading characteristics and particle size distribution.

\section{Introduction}

Recently, the world was shocked by the loss of villages during earthquake with magnitude, Mw 7.5 hit Sulawesi, Indonesia on September 28, 2018. This phenomenon is known as soil liquefaction. This incident was not the first time in the world but was reported occurred since 1964 in Japan. Since 1964, when the Niigata and Alaska earthquakes caused dramatic damages due to soil liquefaction, research efforts have been conducted by engineering profession over the world. Many empirical evidences have been made to understand and reveal the soil liquefaction mechanisms and the factors contributed to the condition. Soil liquefaction is the secondary effect of an earthquake; it is a phenomenon where some saturated granular soils may compact, resulting in increasing pore water pressure, thereby decreasing the effective stress during earthquake which results in a loss of shear strength [1]. The liquefied soil with loss of shear strength may cause terrible and tremendous destruction due to the soil's inability to support the structure. The past example of the structural damage due to liquefaction is the Niigata earthquake on June 16, 1964 which caused failures on bearing capacity, building settlement, and surface paving material [2]. One of the recent large-scale damages due to liquefaction is the 11 March 2011, Tohoku Earthquake (Mw 9.0) in the Tokyo Bay area of Japan [3] [4]. 

Fig. 1 shown that Malaysia is generally located outside the zone of frequent earthquakes and volcanic activities which is also known as Ring of Fire. However, [6] produced an updated map that illustrates the zone of frequent earthquakes and volcanoes activities as shown in Fig. 2. Hence, from Fig. 2, the assumption that Malaysia is immune from earthquake is no longer true since Malaysia (East Malaysia) lies within the Ring of Fire.

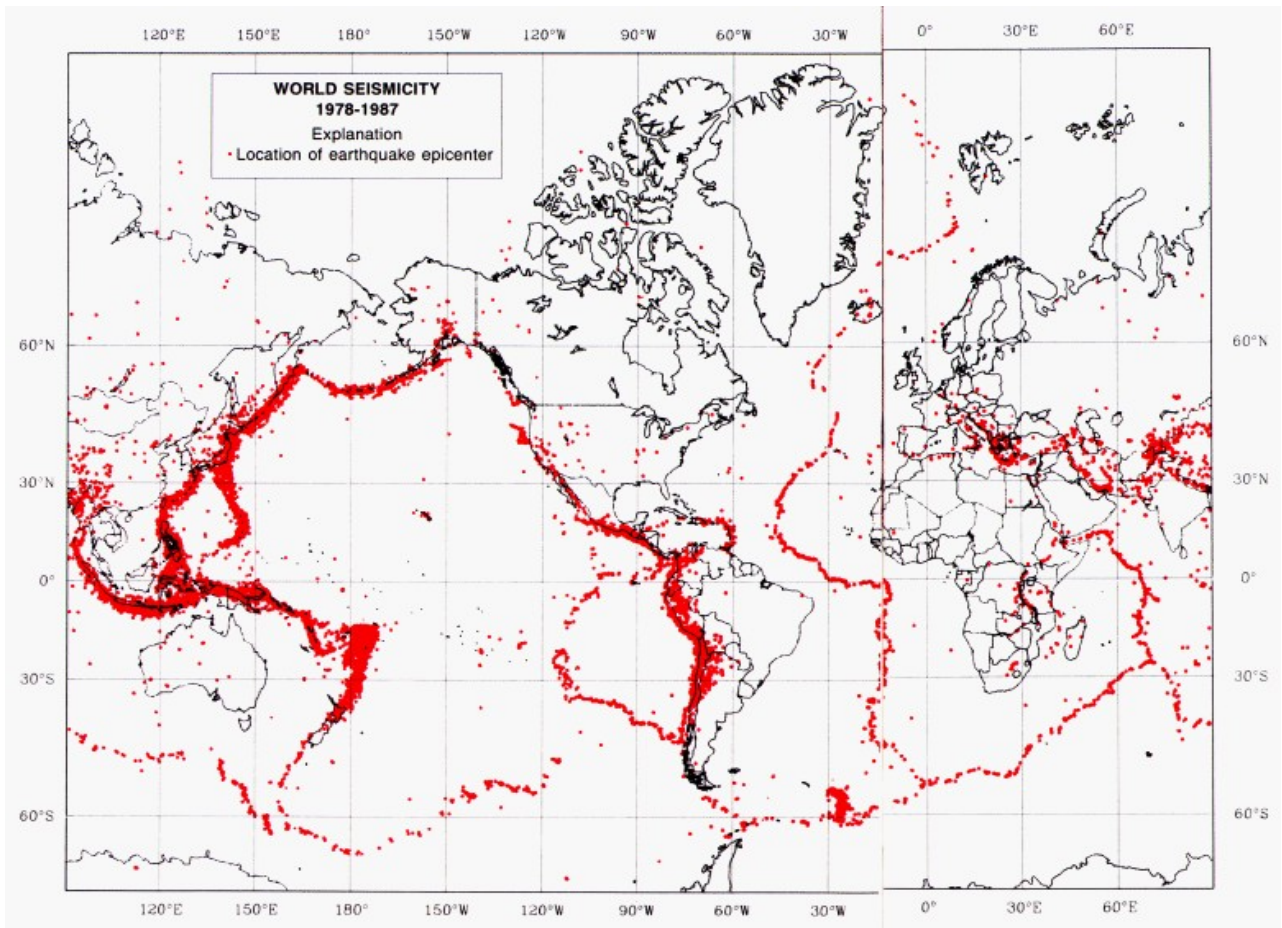

Fig. 1 - Seismicity activities map of the world from year 1978 to 1987 [5].

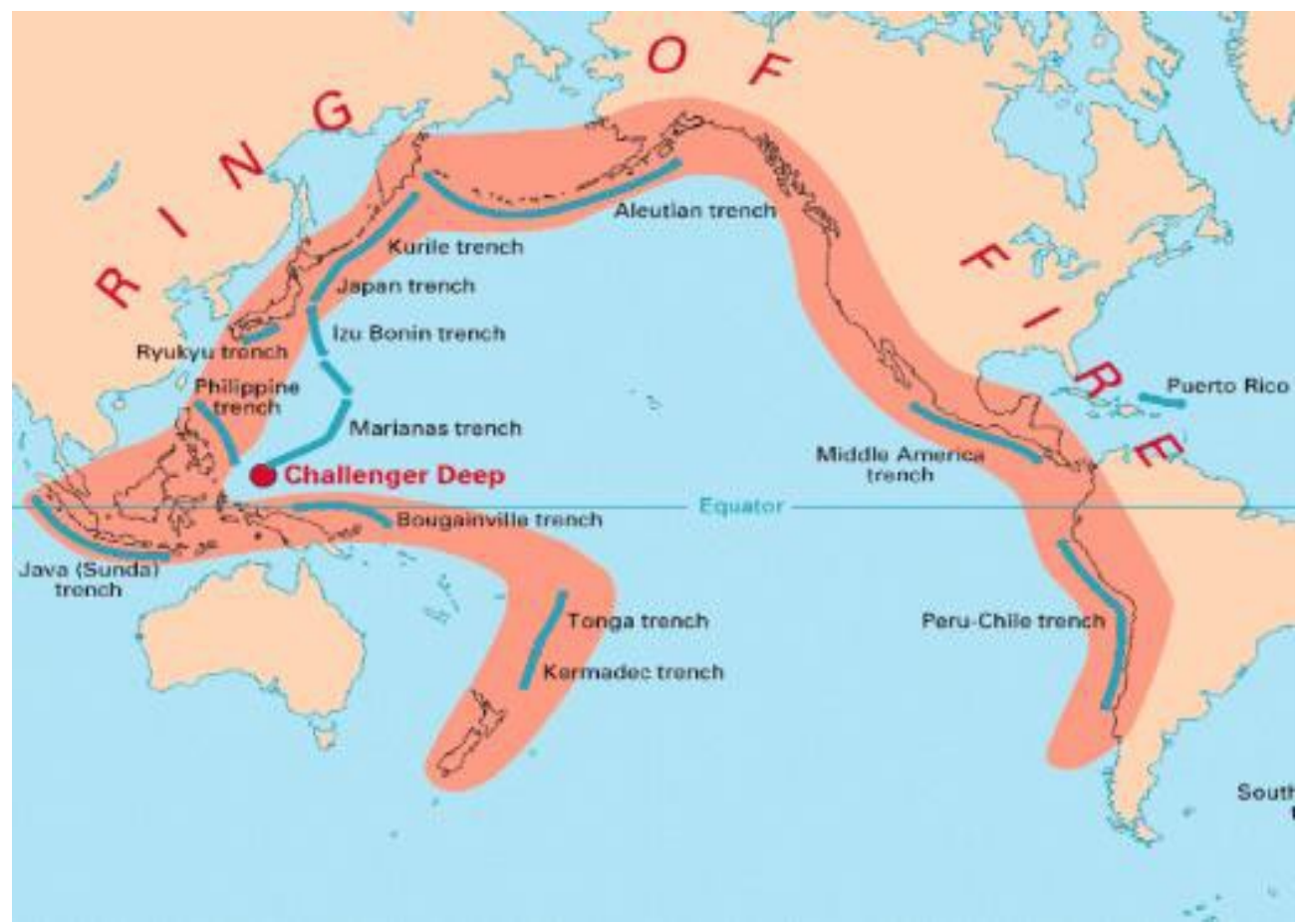

Fig. 2 - Ring of Fire (the red zone with frequent earthquakes and volcanics activities) [6].

In June 2015, an earthquake of Mw 5.9 had occurred in Sabah, East Malaysia. This incident caused 18 deaths and damages to a lot of properties. Although earthquake has never been recorded before in Peninsular Malaysia, since 2007 some incidences have surfaced. For example, minor earthquake had occurred in Janda Baik, Bentong, Pahang in November 2007; in Jerantut, Pahang in March 2009; subsequently in Manjung, Perak on 29 April 2009; and finally in 
the southern areas such as in Kuala Pilah, Negeri Sembilan on 30 November 2009. All of the resulting vibrations were less than Mw 3.5 and were categorized as weak (Malaysian Meteorological Department) and did not cause damage to the building or house.

As indicated by [7], the early assumption that Malaysia is immune from earthquake is misleading. The seismic risk in Malaysia is expected to continue into the next decade due to the projected population and economic growth. This challenge is affecting local construction treads and is threatening the ability to construct quality and sustainable structures. As indicated by Minister of Housing and Local Government Ministry in [8], the local construction industry must take into consideration the seismic aspect in the future building design code. As way forward, the Ministry of Works, Malaysia through speech by Minister of Works on Seminar on Geotechnical Earthquake Engineering in year 2016 shows we must be concerned and vigilant about the risks and consequences of this natural disaster (earthquake, landslide, liquefaction, etc. under stresses of seismic waves) and we need to take seriously and religiously to protect lives and our well-being. The detailed study due to the earthquake must be conducted to produce appropriate adjustment to current practice and policies.

To date, not much studies done on the liquefaction susceptibility in Malaysia due to the earthquake. Therefore, it becomes essential to develop fundamental understanding before amendment and improvement can be made on policies and design code. In order to improve the fundamental understanding on the liquefaction phenomenon, this paper review focuses on bringing an understanding on factors influencing liquefaction resistance in sand-fine mixtures soil. Some of the gap and improvement to the next study will be concluded in the end of this paper review.

\section{Factors Influencing Liquefaction Resistance}

Common earthquake damage is due to tectonic surface processes (plates collide into one another causing the ground surface to squeeze, fold, deform, and move upward) and secondary effect (occurred on non-tectonic surface processes) [2]. [1] stated three (3) major factors that give an effect to the soil behavior during earthquake a) the nature of soil, b) the environment of the soil (static stress state and water content), c) the nature of the dynamic loading (strain magnitude, strain rate, and number of cycles of loading). Liquefaction is one of the secondary effects due to earthquake shaking. Based on in-situ and laboratory testing results, the factors influencing liquefaction are earthquake intensity and duration, ground water table, soil type, relative density of soil, particle size gradation, depositional environment, confining pressure, particle shape, aging and cementation, historical environment, and etc [2]. [9] also summarized another factors involved such as over consolidation ratio, initial stress of the soil, initial pore pressure, mean grain size of the soil $\left(\mathrm{D}_{50}\right)$, and applied peak acceleration.

[2] stated that the cohesionless (non-plastic) soils are susceptible to liquefy. Past studies and research have been intensively focusing on the clean sand as shown in [10], [11] and [12]. But, naturally sand-fine mixtures have also suffered from liquefaction [11] [13] [14]. The chart in Fig. 3 shows the proposed ranges of grain size distribution for potentially liquefiable soil and most liquefiable soil [11]. This chart has been used widely such as [9], [13], [15] and [16] to indicate liquefaction potential. However, this chart limited to clean sand which containing a little or no fine contents. Research conducted by [17] on liquefaction assessment along shoreline of Peninsular Malaysia using this chart shows that, the west coast of Malaysia has low potential liquefaction compared with east coast of Malaysia. As comparable, the shoreline of east coast of Malaysia consist of medium types of sand, while west coast of Johor consists of fine to medium type sand deposited. On the other hand, there some cases from shoreline of Negeri Sembilan, Malaysia which soils have a grain size distribution laid in the boundaries of potentially liquefiable soil. However, previous study conducted by [18] using Nevada fines sand shows oppositely.

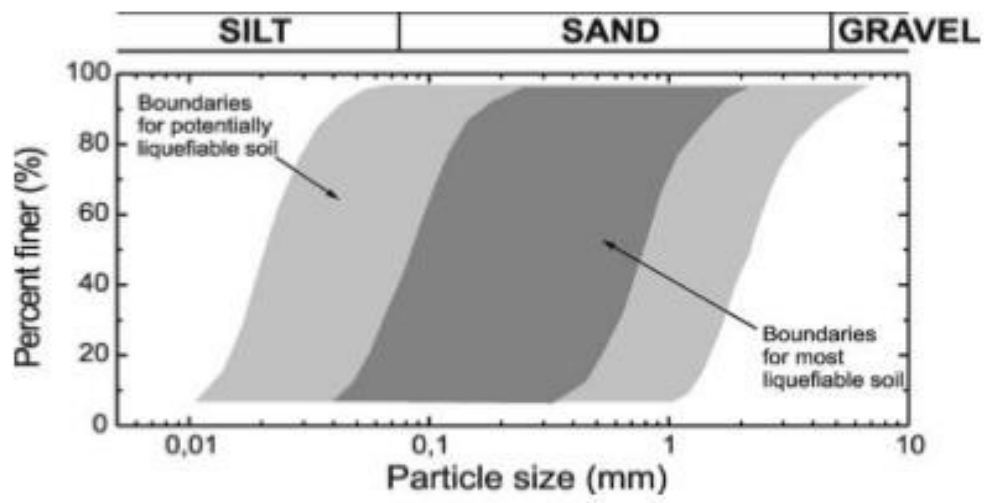

Fig.3 - Grain size distribution boundaries for liquefaction [11]. 


\title{
3. Sand-Fine Mixtures
}

Uniformly graded non-plastic soil tends to form more unstable particle arrangements and is more susceptible to liquefaction than well-graded soils. Well-graded soils will also have small particles that fill in the void spaces between the large particles. This tends to reduce the potential contraction of the soil, resulting in less excess pore water pressure being generated during the earthquake [2]. [19] and [20] have performed the studies on sand-silt mixtures. [20] proposed a conceptual framework (Fig. 4) through microstructure and the relevant grain contact also with the equivalent void ratios. Based on Fig. 4, it shows that the intergranular voids between sand grains decreased with increasing of fines content. At certain condition where the voids fully filled with fines content it's called threshold value or critical fine content, $\mathrm{FC}_{\mathrm{th}}$. [21] carried out the test on sand-fines mixtures and found that the $\mathrm{FC}_{\text {th }}$ value was different using bentonite and kaolin as fines content. At $\mathrm{FC}_{\mathrm{th}}=25 \%$ of kaolin and $\mathrm{FC}_{\mathrm{th}}=20 \%$ of bentonite, lowest undrained shear strength has been recorded. Earlier, [18] summarized the effect fines content with different types of sand. Based on their works, it showed that the presence of fines, sand sizes, particle shape, types of fines and depositional method used may increases or decreases the liquefaction resistance of soils. However, [11] stated this framework proposed by [14] assumed the soil mixtures to be composed by spherical particles.

(a) Coarse grain soil mix

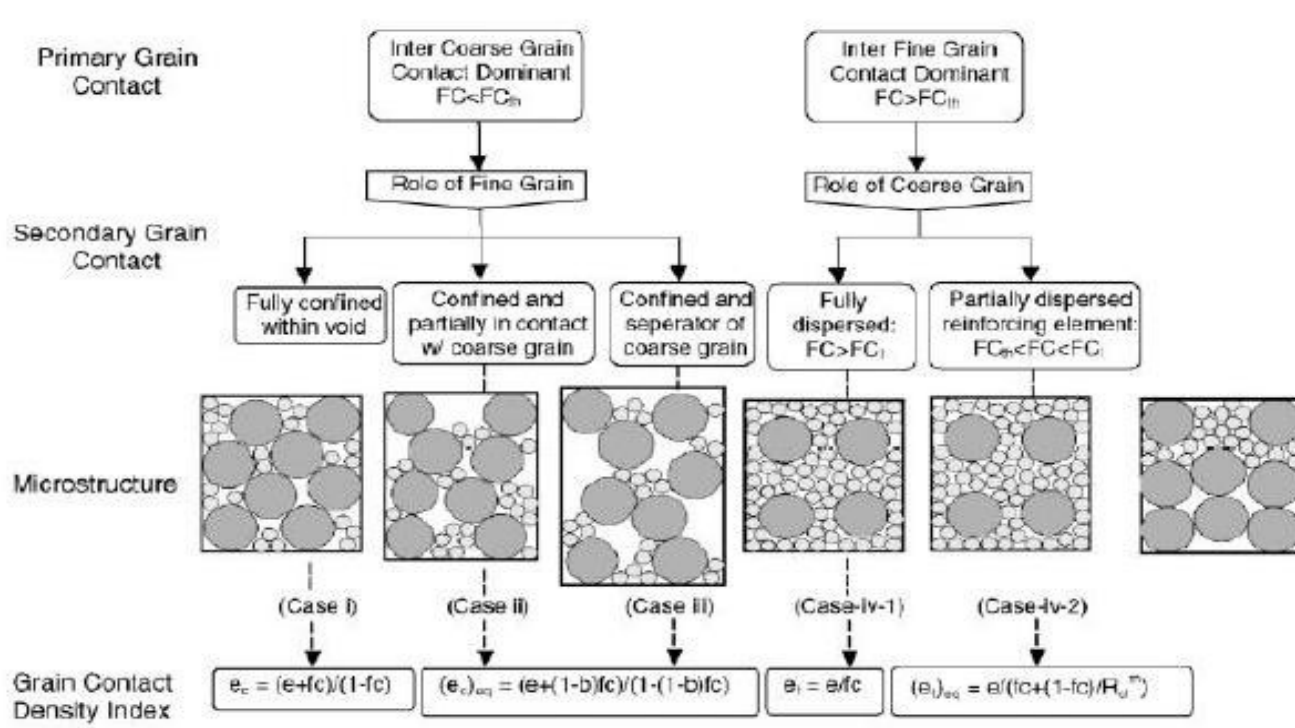

(c) Layered soil mix

\begin{abstract}
$b=$ portion of the fine grains that contribute to the active intergrain contacts; $e=g$ lobal void ratio; $F C=f i n e$ grains content;

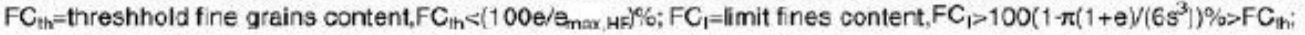

$m$ : reinforcement factor; $A_{c}=D / d=$ particle size disperity ratio; $s=1+a / R_{b}, a=10 ; e_{m s x} . H F$ the maximum void ratio of host fine
\end{abstract}

Fig. 4 - Intergranular soil mix classification for the conceptual framework [20].

Generally, the presence of fine in sand-fine mixtures may reduces or increases the liquefaction susceptibility. Physical studies on sand and sand mixtures done by previous researchers have been summarized by [12]. It stated the confining pressure, relative density, degree of saturation, sample preparation method, over-consolidation ratio, and stress ratio have been well presented but further studies on fines content, structure, grading characteristics, and size and shape of particles still need to be completed. [22] has shown the same factors to be carried out as studied by [12] but with addition of membrane penetration and partial drainage. [23] stated that, although the liquefaction has been intensively studied and published, but not much results can be concluded on the influence of particle size distribution (in term of mechanical behaviour of granular material).

\section{Microstructure of Clay and Sand-Fine Mixtures}

Clay minerals basically consist of two basic units: silica tetrahedron and alumina octahedron. The combination of these two basic units gives an aluminium silicate. Fig. 5 shows the combination of the basic units. 


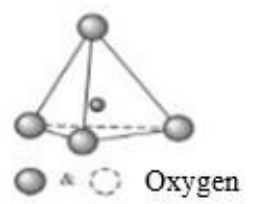

(a)

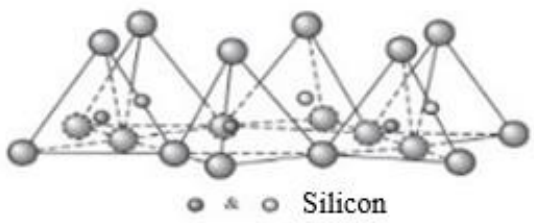

(b)

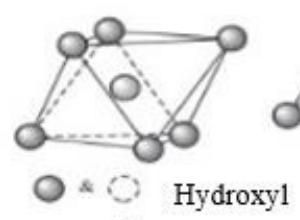

(c)

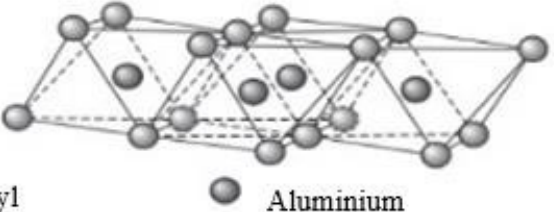

(d)

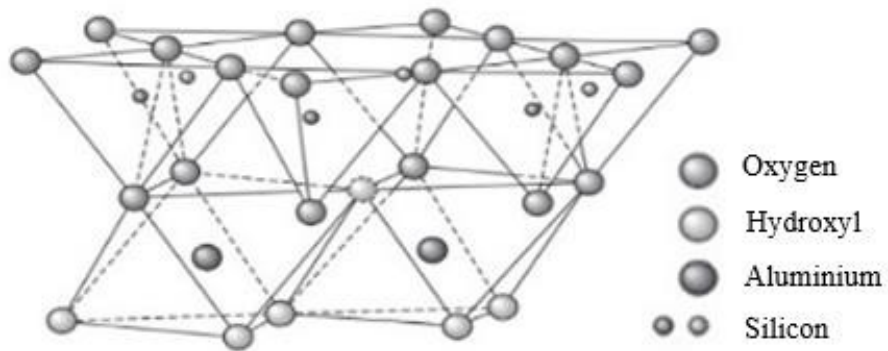

(e)

Fig. 5 - (a) Silica tetrahedron;(b) silica sheet; (c) alumina octahedron; (d) octahedral (gibbsite) sheet; (e) elemental silica - gibbsite sheet [24].

Repeating or combination of Silica-Gibbsite formed kaolinite, illite, montmorillonite, nacrite, and etc. are present in soil. Smectite, hematite, imogolite, halloysite, palygorskite, sepiolite, allophane and goethite are nanoparticles which exist in soil environment [25]. Kaolinite, elite, montmorillonite, chlorite, vermiculite, and attapulgite are also presents in clay minerals [24]. The nanomaterials have a different specific surface such as kaolin (about $15 \mathrm{~m}^{2} / \mathrm{g}$ ), illite (about $\left.80 \mathrm{~m}^{2} / \mathrm{g}\right)$, and montmorillonite $\left(800 \mathrm{~m}^{2} / \mathrm{g}\right)$. [26] determined that kaolin is a product of a weathering process of primary minerals and its major component is fine grain kaolinite $(<2 \mu \mathrm{m})$. Kaolin also contains aluminium and iron phyllosilicate as the pigment. [27] determined that the most mineral content in clay fraction is kaolinite. The study on the soil in Peninsular of Malaysia shows that kaolinite mineral occupied $40 \%$ to $60 \%$ of the clay fraction, with the rest is composited by chlorite, smectite, vermiculite and others. [26] shows that from 25 samples of kaolin in Johor, Malaysia the colour of kaolin is light due to high silicate composition, with kaolinite and quartz are the highest mineral content.

Recently, new steps have been taken by [28], [29] and [30] on the use and effect of nanomaterials in soil. [31] and [32] have conducted a study and have proved the nanomaterials have effectively improved liquefaction resistance. The use of laponite for liquefaction mitigation shows the nanomaterial effectiveness as a mitigation method. [27] conducted a series of tests on terrace soils of peninsular Malaysia to investigate the mineralogy and physicochemical characteristics of the soil. Table 1 below summarized the effect of texture and drainage conditions on the formation of gibbsite in soil sample. It shows the high amount of gibbsite will give a better drainage in soils.

Table 1 - The effect of texture and drainage conditions on the formation of gibbsite (modified from [27])

\begin{tabular}{cccc}
\hline Texture & Series & Drainage & $\begin{array}{c}\text { Gibbsite } \\
\text { (clay) \% }\end{array}$ \\
\hline Sandy & Sg. Buloh (7) & excessive & 63.3 \\
& Sg. Buloh (8) & excessive & 10.1 \\
& Subang (10) & poor & 4.3 \\
Coarse & Nangka (1) & well & 8.6 \\
Loamy & Lintang (6) & well & 8.6 \\
Fine & Bt. Tuku (3) & imperfect & 1.6 \\
Loamy & Rasau (14) & well & 2.9 \\
Clayey & Kg. Pusu (2) & poor & 2.2 \\
& Kerayong (4) & moderate & 2.5 \\
\hline
\end{tabular}


[33] employed the compositions of sand-fine mixtures with different percentage of fines content in term of Scanning Electron Microscope (SEM) micrographs. Silt was applied as fines content to reconstitute sand-fine mixtures. Their results show that at $15 \%$ of silt, there are still void between the grains. The void decreased when the fines content increased. Fig. 6 showed at $70 \%$ of silt, the voids have been fully filled by fines. On the other hand, they found that the increasing of silt content contributed to the strength reduction until threshold value of $30 \%$ of fines, then the strength was increased. This finding was in a great agreement with research conducted by [21] on the threshold value.
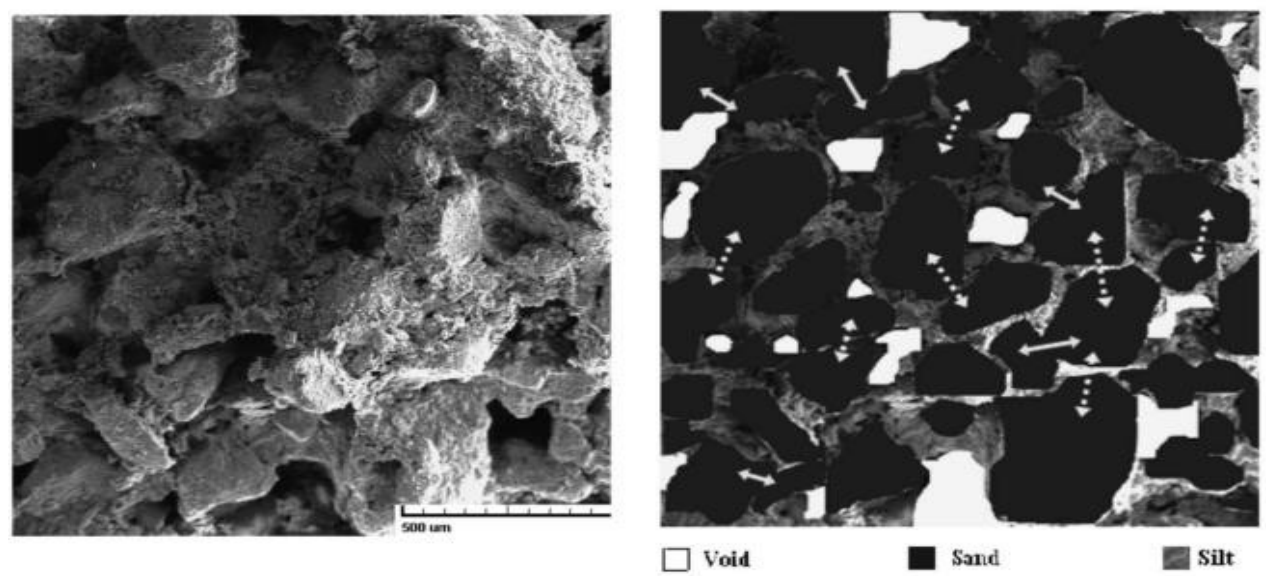

(a) $15 \%$ of fines
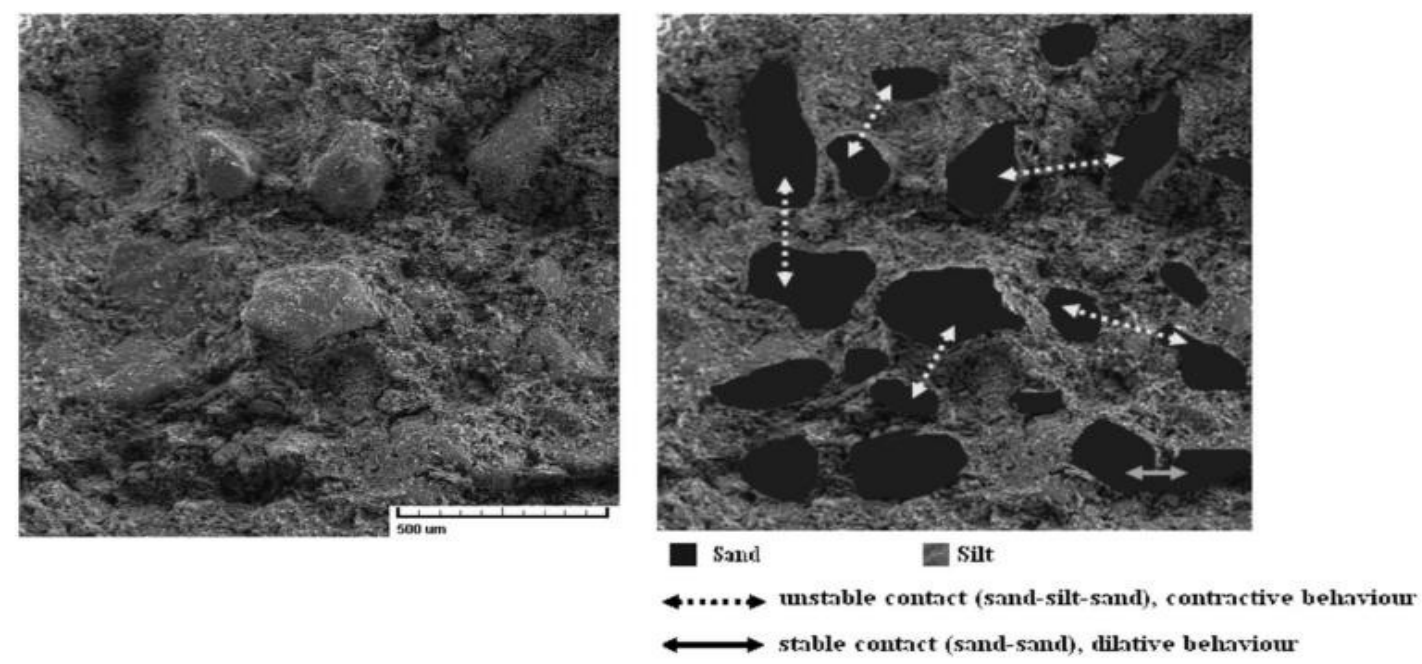

(b) $70 \%$ of fines

Fig. 6 - (a) (b) SEM micrograph of different percentage of fines content in sand-fine mixtures [33].

\section{Grading Characteristics and Particle Size Distribution of Sand-Fine Mixtures}

[34] shows some results published by past researchers from year 1968 to 1999 on the effects of particle size gradation on the liquefaction resistance. From those results, some researchers claim mean grain size $\left(\mathrm{D}_{50}\right)$ of $1.0 \mathrm{~mm}$ to $0.1 \mathrm{~mm}$ causes decreasing in liquefaction resistance. On the other hand, some researchers show the $\mathrm{D}_{50}$ of $0.08 \mathrm{~mm}$ are more susceptible to liquefy. Evaluation on field case histories of liquefaction potential for 50 years around the world have been figured out by [13] based on research done by [16]. From Fig. 7, [13] shows that about 78\% liquefaction from 155 incidents occur when the mean grain size, $\mathrm{D}_{50}$ is between $0.113 \mathrm{~mm}$ to $0.338 \mathrm{~mm}$. However, laboratory testing conducted by [18] shows that $\mathrm{D}_{50}=0.6 \mathrm{~mm}$ to $0.43 \mathrm{~mm}$ also liquefy with additional factors such as particle shape and the fine content. Results from [34] shows there is no relationship can be concluded between $\mathrm{C}_{U}$ and cyclic resistance, and also the $\mathrm{C}_{\mathrm{C}}$ and cyclic resistance. The results have been shown in agreement with [22], which conducted studies on Khazar coastal sand at different percentage of mixtures, that it is hard to find a relationship between $\mathrm{C}_{\mathrm{C}}$ or $\mathrm{C}_{\mathrm{U}}$ to cyclic resistance as liquefaction indicator. Consequently, the influence of membrane penetration and system 
compliance need to be carried out before the concrete results on the relationship can be drawn. Experimental study has been carried out by [35] on the effect of grading characteristics of the sand-mixtures. The results show that the undrained shear strength at the peak decreases with the increases of $\mathrm{C}_{\mathrm{U}}$ and $\mathrm{C}_{\mathrm{C}}$. Although the recent results show a good correlation, there is still no clear conclusion to describe this relationship. Shear box test conducted by [36] and [37] shows that the gradation plays an important effect to the shear strength parameter. Table 2 summarized some of the recent studies on grading characteristics and particle size distribution, and also other findings through the studies on sand mixtures. It shows that the liquefaction resistance may decrease or increase with effect of densities of soils, fines content, particles angularity, grading characteristics $\left(\mathrm{D}_{60}, \mathrm{D}_{50}, \mathrm{D}_{30}, \mathrm{D}_{10}, \mathrm{C}_{\mathrm{U}}, \mathrm{C}_{\mathrm{C}}\right)$, particle size and threshold value.

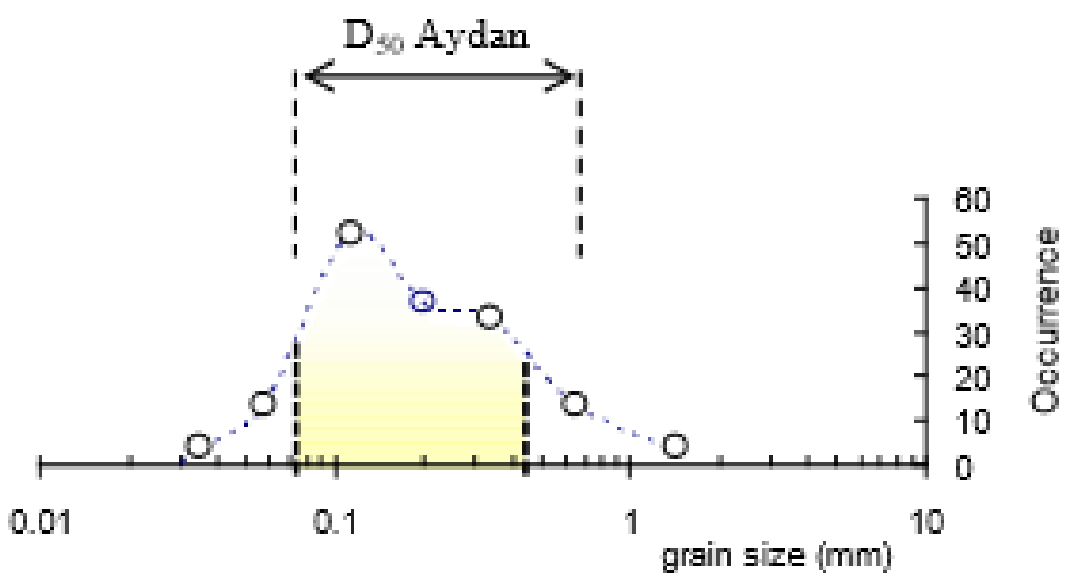

Fig.-7. D50 for liquefied soils [13].

Table 2 - Summary of some related studies on grading characteristics and particle size distribution in sand-fine mixtures

\begin{tabular}{|c|c|c|c|c|c|}
\hline \multirow[b]{2}{*}{$\begin{array}{l}\mathbf{N} \\
\mathbf{0 .}\end{array}$} & \multirow[b]{2}{*}{$\begin{array}{l}\text { Researcher } \\
\text { s }\end{array}$} & \multirow[b]{2}{*}{$\begin{array}{l}\text { Te } \\
\text { st }\end{array}$} & \multirow[b]{2}{*}{ Reconstituted Samples } & \multicolumn{2}{|c|}{ Findings } \\
\hline & & & & $\begin{array}{l}\text { Grading and } \\
\text { particle }\end{array}$ & $\begin{array}{l}\text { Othe } \\
\text { rs }\end{array}$ \\
\hline 1 & {$[2$} & $\begin{array}{l}\text { Undrained } \\
\text { ring shear } \\
\text { te }\end{array}$ & $\begin{array}{l}\text { Natural Osaka soil } \\
\text { (Well-graded, } \\
\text { graded, Narrowly graded } \\
\text { and Gap graded sample). }\end{array}$ & $\begin{array}{l}\text { At higher densities, } \\
\text { Well-graded samples } \\
\text { shows higher peak } \\
\text { strength than other } \\
\text { grade. }\end{array}$ & $\begin{array}{l}\text { Liquefaction } \\
\text { depend more on } \\
\text { relative densities } \\
\text { rather than on } \\
\text { gradation. }\end{array}$ \\
\hline 2 & {$[1$} & $\begin{array}{l}\text { Triaxial } \\
\text { (Monotoni } \\
\text { and }\end{array}$ & $\begin{array}{l}\text { JCA sand } \\
\text { (Stratified sand). }\end{array}$ & $\begin{array}{l}\text { Different gradation of } \\
\text { soil cause different } \\
\text { undrained behaviour. }\end{array}$ & \\
\hline 3 & {$[3$} & $\begin{array}{l}\text { Triaxial } \\
\text { (Cyclic) }\end{array}$ & $\begin{array}{l}\text { Pasabahce Silica } \\
\text { (No. } 16-\text { No. } 18 \text { is mixed } \\
\text { with different percentage } \\
\text { of } 0-100 \% \text { of } 11 \text { subgroup } \\
\text { (No. } 18 \text { to No. } 400 \text { based } \\
\text { on USCS)). }\end{array}$ & & $\begin{array}{l}\text { Fine content } \\
\text { increases (constant } \\
\text { Dr } 60 \% \text { ), the } \\
\text { Resistance to } \\
\text { liquefaction } \\
\text { decreases }\end{array}$ \\
\hline 4 & {$[3$} & $\begin{array}{l}\text { Triaxial } \\
\text { (Monotoni }\end{array}$ & $\begin{array}{l}\text { Sydney Sand } \\
\text { (Reconstituted sample s } \\
\text { Sydney Sand with } 1 / 3 \\
\text { kaolin, Majura silt with } \\
\text { kaolin). }\end{array}$ & & $\begin{array}{l}\text { The angularity of } \\
\text { fines plays an } \\
\text { important role on } \\
\text { the behavior of } \\
\text { sand-fine }\end{array}$ \\
\hline 5 & {$[4$} & $\begin{array}{l}\text { Triaxial } \\
\text { (Monotoni } \\
\text { and }\end{array}$ & $\begin{array}{l}\text { Reconstituted specimens : } \\
\text { Grain diameter : } 1 . \\
0.075 \mathrm{~mm}-0.25 \mathrm{~mm} \text { (pure } \\
\text { sand), } 2 . \text { Smaller than } \\
0.075 \mathrm{~mm} \text { (fine grain). } \\
\text { Chlef Sand (Reconstituted } \\
\text { samples of Chlef Sand } \\
\text { with silt at percentage of }\end{array}$ & $\begin{array}{l}\text { Cyclic resistance of } \\
\text { sand-silt mixture } \\
\text { decreases linearly }\end{array}$ & $\begin{array}{l}\text { Liquefaction } \\
\text { resistance } \\
\text { with addition of } \\
\text { non-plastic fines } \\
\text { to } 30 \% \text {. }\end{array}$ \\
\hline
\end{tabular}




\begin{tabular}{|c|c|c|c|c|c|}
\hline \multirow[b]{2}{*}{$\begin{array}{l}\mathbf{N} \\
\mathbf{0 .}\end{array}$} & \multirow{2}{*}{$\begin{array}{l}\text { Researcher } \\
\text { s }\end{array}$} & \multirow[b]{2}{*}{$\begin{array}{l}\text { Te } \\
\text { st }\end{array}$} & \multirow[b]{2}{*}{ Reconstituted Samples } & \multicolumn{2}{|c|}{ Findings } \\
\hline & & & & Grading and & Othe \\
\hline & & & $50 \%)$ & \begin{tabular}{l}
\multicolumn{1}{c}{ particle } \\
decreases of effective \\
diameter and mean \\
size.
\end{tabular} & \\
\hline 7 & {$[2$} & $\begin{array}{l}\text { Triaxial } \\
\qquad \text { (Cyclic) }\end{array}$ & $\begin{array}{l}\text { Khazar coastal sand } \\
\text { (Reconstituted samples of } \\
\text { gravel and coarse sand } \\
\text { separately mixed with } \\
\text { Khazar coastal sand at } 0 \text {, } \\
10,25,40,50,60,70 \text { and } \\
100 \% \text { by dry mass). }\end{array}$ & $\begin{array}{l}\text { a) Fine Grained } \\
\mathrm{D}_{10}, \mathrm{D}_{30}, \mathrm{D}_{50} \text { and } \mathrm{D}_{60} \\
\text { decreases, } \\
\text { resistance decreases. } \\
\text { b) Coarse Grained } \\
\text { Sand : } \mathrm{D}_{10}, \mathrm{D}_{30}, \mathrm{D}_{50} \\
\text { and } \\
\mathrm{D}_{60} \text { increase, } \\
\text { increases. }\end{array}$ & \\
\hline 8 & {$[4$} & $\begin{array}{l}\text { Triaxial } \\
\text { (Monotoni }\end{array}$ & $\begin{array}{l}\text { Reconstituted of Sand- } \\
\text { fines mixtures } \\
\text { (Host sand : Sydney } \\
\text { Fines : Natural soil silt } \\
\text { from Majura River bank } \\
\text { and commercial kaolin). }\end{array}$ & & $\begin{array}{l}\text { Liquefaction } \\
\text { resistance } \\
\text { with increases of } \\
\text { fines content. }\end{array}$ \\
\hline 9 & {$[42]$} & $\begin{array}{c}\text { Drained } \\
\text { simple shear } \\
\text { tests }\end{array}$ & $\begin{array}{l}\text { Reconstituted samples of } \\
\text { sand-gravel } \\
\text { (Crushed coarse } \\
\text { aggregates mix with } \\
\text { clean sand as fine } \\
\text { content). }\end{array}$ & $\begin{array}{l}\text { In well-graded } \\
\text { mixtures, the inclusion } \\
\text { of gravel particles } \\
\text { generally reduces } \\
\text { the shear resistance } \\
\text { as the } \\
\text { gravel content }\end{array}$ & \\
\hline 10 & [43] & $\begin{array}{l}\text { Triaxial } \\
\text { (Monotoni }\end{array}$ & $\begin{array}{l}\text { Reconstituted samples of } \\
\text { sand mixtures } \\
\text { (Coarse material of } \\
50 / 70 \text { as sand poor graded } \\
\text { mixed with } \\
\text { kaolinite clay). }\end{array}$ & & $\begin{array}{l}\text { Critical fines } \\
\text { content occurring } \\
\text { approximately } \\
\text { of fines content. }\end{array}$ \\
\hline 11 & [44] & $\begin{array}{l}\text { Ring shear } \\
\quad \text { te } \\
\text { (Cyclic } \\
\text { Monotonic }\end{array}$ & $\begin{array}{l}\text { Reconstituted of non- } \\
\text { plastic silt and sandy silts } \\
\text { with } 50 \% \text { and } 75 \% \text { of silt } \\
\text { content. } \\
\text { Silt (grinding of silica } \\
\text { by US Silica Company). }\end{array}$ & & $\begin{array}{l}\text { Cyclic resistance } \\
\text { ratio of silt and } \\
\text { sandy silts } \\
\text { decreases with } \\
\text { increasing of void } \\
\text { ratio, or with } \\
\text { decreasing silt } \\
\text { content at certain } \\
\text { void ratio. }\end{array}$ \\
\hline 12 & {$[45]$} & $\begin{array}{l}\text { Reporting } \\
\text { data - } \\
\text { photograp } \\
\quad \text { a } \\
\text { observatio } \\
\text { on particle } \\
\text { size }\end{array}$ & $\begin{array}{l}\text { Data from } \mathrm{M}_{\mathrm{w}} 7.9 \text { of } \\
2008 \text {. }\end{array}$ & $\begin{array}{l}\text { Sand boils are } \\
\text { dominated by sandy } \\
\text { material with } \\
\text { of } 0.0625-1.0 \mathrm{~mm} \text {. }\end{array}$ & \\
\hline 13 & [13] & $\begin{array}{l}\text { Round } \\
\text { container } \\
\text { a shaking } \\
\text { table }\end{array}$ & $\begin{array}{l}\text { Sand from Pasir Jambak, } \\
\text { Indonesia } \\
\text { (Sample on several depth } \\
\text { collected and tested depth } \\
0.5 \mathrm{~m}, 1 \mathrm{~m}, 1.5 \mathrm{~m} \text { and }\end{array}$ & $\begin{array}{l}\text { Liquefaction } \\
\text { of the sands increases } \\
\text { with increases of } \\
\text { relative density and } \\
\text { mean particle size. }\end{array}$ & \\
\hline 14 & {$[46]$} & $\begin{array}{l}\text { Triaxial } \\
\text { (Monotoni }\end{array}$ & $\begin{array}{l}\text { Johor clean sand. } \\
\text { (Reconstituted samples of } \\
\text { kaolin and bentonite } \\
\text { (fines) mixed with Johor }\end{array}$ & & $\begin{array}{l}\text { Threshold value of } \\
\text { fines for sand- } \\
\text { kaolin is } 25 \% \\
\text { sand-bentonite at }\end{array}$ \\
\hline
\end{tabular}




\begin{tabular}{|c|c|c|c|c|c|}
\hline \multirow[b]{2}{*}{ No. } & \multirow[b]{2}{*}{ Researchers } & \multirow[b]{2}{*}{ Test } & \multirow[b]{2}{*}{ Reconstituted Samples } & \multicolumn{2}{|c|}{$\begin{array}{c}\text { Findings } \\
\end{array}$} \\
\hline & & & & $\begin{array}{c}\text { Grading and particle } \\
\text { size }\end{array}$ & Others \\
\hline & & & $\begin{array}{l}\text { clean sand at } 0-40 \% \text { of } \\
\text { fines content). }\end{array}$ & & \\
\hline
\end{tabular}

\section{Conclusion}

Research on the effect of grading characteristics and particle size distribution of sand on liquefaction resistance of sand-fine mixtures is still limited. To the best of our knowledge, the studies using tropical sand and clay or silt on liquefaction resistance in Malaysia is still lacking in general, particularly in tropical area like Malaysia. The conclusions that can be drawn are as follows:

- The effect of grading characteristics and particle size distribution of sand on liquefaction resistance need more comprehensive studies. According to the review, the results on the mean grain size and grading characteristics of sand-fine mixtures in liquefaction resistance is still contradictory.

- The microscopy and macroscopy structure studies are proposed and need to be conducted to assist on verification of the behaviour of sand-fine mixtures.

- The effect of angularity, shape and contact area of soil particles, drainage conditions of microstructure, and membrane penetration and partial drainage are among the factors that requires further studies in the future.

\section{Acknowledgement}

The financial support from the Ministry of Higher Education (MOHE), Malaysia through Fundamental Research Grant Scheme (FRGS), No. PY/2016/07185, Vot. R.J130000.7822.4F849 is greatly acknowledged. The provision of the student incentive undertaking the studies from Malaysia-Japan International Institute of Malaysia (MJIIT), Universiti Teknologi Malaysia Kuala Lumpur is also highly appreciated.

\section{References}

[1] Dowrick, D. (2009). Earthquake Resistant Design and Risk Reduction (2 ${ }^{\text {nd }}$ ed.). 2009, John Wiley \& Sons, Ltd. [2] Day, R.W. (2012). Geotechnical Earthquake Engineering Handbook ( $2^{\text {nd }}$ ed.). The McGraw-Hill Companies, Inc. [3]

Sana, H. \& Nath, S.K. (2016). Liquefaction Potential Analysis of the Kashmir Valley Alluvium, NW Himalaya.

Soil Dynamics and Earthquake Engineering, 85, 11-18.

[4] Bhattacharya, S., Hyodo, M., Goda, K., Tazoh, T. \& Taylor, C.A. (2011). Liquefaction of Soil in the Tokyo Bay Area from the 2011 Tohoku (Japan) Earthquake. Soil Dynamics and Earthquake Engineering, 31, 1618-1628.

[5] United State Geological Survey (USGS) (2016). https://pubs.usgs.go v/gip/earthq4/severitygip.html.

[6] Lindeberg, P. (2001). This Dynamic Earth: The Story of Plate Tectonic. U.S. Government Printing Office, Washington. DC. Online edition.

[7] Marto, A., Tan, C.S., Kassim, F., Mohd. Yunus, N.Z. (2013). Seismic Impact in Peninsular Malaysia. In the 5th International Geotechnical Symposium-Incheon (pp. 237-242). Seoul, South Korea.

[8] The Star. (2012). Plans to Amend Uniformed Buildings By-Law to Prepare for Earthquakes.

[9] Das, B.M. (1983). Advanced Soil Mechanics. Hemisphere Publishing Corp, McGraw Hill, London 1983.

[10] Yoshimine, M., Koike, R. (2005). Liquefaction of Clean Sand with Stratified Structure Due to Segregation of Particle Size. Soils and Foundations. Vol. 45, No.4, 89-98, Aug. 2005 Japanese Geotechnical Society.

[11] Xenaki, V.C., Athanasopoulos, G.A. (2003). Liquefaction Resistance of Sand - Silt Mixtures : An Experimental Investigation of the Effect of Fines. Soil Dynamics and Earthquake Engineering, 23, 183-194.

[12] Bayat, E., Bayat, M. (2013). Effect of Grading Characteristics on the Undrained Shear Strength of Sand: Review With New Evidence. Arab Journal of Science, 6, 4409-4418.

[13] Hakam, A., Ismail, F.A. \& Fauzan (2016). Liquefaction Potential Assessment Based on Laboratory Test. International Journal of Geomate,11(26), 2552-2557.

[14] Thevanayagam, S. (2000). Liquefaction Potential and Undrained Fragility of Silty Soils. Proceedings of 12th World Conference on Earthquake Engineering. Auckland, New Zealand; 2000. p. 8.

[15] Hakam, A. (2016). Laboratory Liquefaction Test of Sand Based on Grain Size and Relative Density. Journal of Engineering and Technological Sciences, 2016, 334-344.

[16] Aydan, O., Ulusay, R. \& Atak, V.O. (2008). Evaluation of Ground Deformations Induced by the 1999 Kocaeli Earthquake (Turkey) at Selected Sites on Shorelines. Environmental Geology, 54(1), 165-182.

[17] Hashim, H. (2016). Soil Liquefaction Hazard Assessment along Shoreline of Peninsular Malaysia. PhD. Thesis. University of Malaya, Malaysia. 
[18] Monkul, M.M. \& Yamamuro, J.A. (2011). Influence of Silt Size and Content on Liquefaction Behavior of Sands. Canadian Geotechnical Journal. 48, 931-942.

[19] Lade, P.V. \& Yamamuro, J.A. (1997). Effects of Nonplastic Fines on Static Liquefaction of Sands. Canadian Geotechnical Journal, 34, 918-928.

[20] Thevanayagam, S. \& Martin, G.R. (2002). Liquefaction in Silty Soil - Screening and Remediation Issues. Soil Dynamics and Earthquake Engineering, 22(9-12), 1035-1042.

[21] Tan, C.S. (2015). Effect of Fines Content and Plasticity on Liquefaction Susceptibility of Sand Matrix Soils. PhD Thesis. Universiti Teknologi Malaysia, Malaysia.

[22] Choobbasti, A.J., Ghalandarzadeh, A. \& Esmaeili, M. (2014). Experimental Study of the Grading Characteristic Effect on the Liquefaction Resistance of Various Graded Sands and Gravelly Sands. Arabian Journal of Geosciences, 7, 2739-2748.

[23] Igwe, O., Sassa, K. \& Fukuoka, H. (2004). Liquefaction Potential of Granular Materials Using Differently Graded Sandy Soils. Annuals of Disas. Prev. Res. Insst., Kyoto Univ., No. 47 B, 2004.

[24] Das, B.M. (2008). Fundamentals of Geotechnical Engineering ( $3^{\text {rd }}$ ed.). Thompsom.

[25] Zhang, G. (2007). Soil Nanoparticles and Their Influence on Engineering Properties of Soil. Conference GeoDenver 2007. February 18-21,2007, Colorado, United States. ASCE.

[26] Hamzah U. \& Learn K.K. (2010). Sifat-Sifat Fizik dan Kandungan Kimia Lempung Kaolin Segamat, Johor. Sains Malaysiana, 39, 31-38.

[27] Shamshuddin, J. \& Tessens E. (1985). Some T Terrace Soils of Peninsular Malaysia : II. Mineralogy and Physicochemical Characteristics. Pertanika, 8(2), 159-168.

[28] Ghasabkolaei, N., Choobbasti, A.J., Roshan, N., Ghasemi, S.E. (2017). Geotechnical Properties of the Soils Modified with Nanomaterials: A Comprehensive Review. Archives of Civil and Mechanical Engineering, 17, 639-650.

[29] Huang, Y. \& Wang, L. (2008). Microscopic Characteristics of Nanoparticles for Seismic Liquefaction Mitigation. The 15th Asian Regional Conference on Soil Mechanics and Geotechnical Engineering. 2008.

[30] Gallagher, P.M. (2000): Passive site remediation for mitigation of liquefaction risk, Ph.D. thesis, Virginia Polytechnic Institute and State University, Virginia, USA.

[31] Mollamahmutoglu, M. \& Yilmaz, Y. (2010). Pre- and post-cyclic loading strength of silica-grouted sand. Proceedings of the ICE - Geotechnical Engineering, 163, 343-348.

[32] Mokhtar, A.A., Abdel-Motaal, M.A. and Wahidy, M.M. (2014). Lateral displacement and pile instability due to soil liquefaction using numerical model. Ain Shams Engineering Journal, 5(4), 1019-1032.

[33] Bahadori, H, Ghalandarzadeh, A, Towhata, I. (2008). Effect of Non Plastic Silt on the Anisotropic Behaviour of Sand. Soils and Foundations. Japanese Geotechnical Society, 48(4), 531-545.

[34] Yilmaz, Y., Mollamahmutoglu, M., Ozaydin, V. \& Kayabali, K. (2007). Experimental Investigation of the Effect of Grading Characteristics on the Liquefaction Resistance of Various Graded Sands. Engineering Geology, 100, 91-100.

[35] Krim, A., Arab, A., Chemam, M., Brahim, A., Sadek, M., \& Shahrour, I. (2017). Experimental study on the liquefaction resistance of sand-clay mixtures: Effect of clay content and grading characteristics. Marine Georesources \& Geotechnology, 2017, 1-13.

[36] Alvin John, L.M.S., Wijeyesekera, D.C., Zainorabidin, A., Bakar, I. (2012). The Integration of the Morphological Aspects of Sand to It's Shear Strength and Dilatancy Characteristics. International Journal of Integrated Engineering, Vol. 4 No. 2 (201x) p. 77-87.

[37] Alvin John, L.M.S., Wijeyesekera, D.C., Zainorabidin, A., Bakar, I. (2012). International Journal of Integrated Engineering - Special Issue on ICONCEES Vol. 4 No. 3 (2012) p. 27-37.

[38] Rahman, M.M. \& Lo, S.R. (2008). Effect of Sand Gradation and Fines Type on Liquefaction Behavior of SandFines Mixture. Geotechnical Earthquake Engineering \& Soil Dynamics IV Congress 2008. May 18-22, 2008. United States.

[39] Wang, Y. \& Wang, Y. (2010). Study of Effects of Fines Content on Liquefaction Properties of Sand. GeoShanghai 2010 International Conference. Soil Dynamics and Earthquake Engineering. ASCE.

[40] Belkhatir, M., Arab, A., Schanz, T., Missoum, H. \& Della N. (2011). Laboratory Study on the Liquefaction Resistance of Sand - Silt Mixtures : Effect of Grading Characteristics. Granular Matter, 13, 599-609.

[41] Rahman, M.M. \& Lo, S.R. (2014). Undrained Behavior of Sand-Fines Mixtures and Their State Parameter. Journal of Geotechnical and Geoenvironmental Engineering, 140(7): -1-1. ASCE.

[42] Chang, W.J. \& Phantachang, T. (2016). Effect of Gravel Content on Shear Resistance of Gravelly Soils. Engineering Geology, 207,78-90.

[43] Simpson, D.C., Evans, T.M. (2016). Behavioral thresholds in mixtures of sand and kaolinite clay. Journal of Geotechnical and Geoenvironmental Engineering, 2016, 1943-5606.

[44] Takch, A.E., Sadrekarimi, A. \& El. Naggar, H. (2016). Cyclic Resistance and Liquefaction Behavior of Silt and Sandy Silt Soils. Soil Dynamics and Earthquake Engineering, 83, 98-109. 
[45] Zeng, JL., Wang, P., Zhang, Z., Li, Z., Cao, Z., Zhang, J, Yuan, X, Wang, W \& Xing, X (2017). Liquefaction in western Sichuan Basin during the 2008Mw7.9 Wenchuan earthquake, China. Tectonophysics, 694, 214-238.

[46] Marlo, A, Tan, C.S., Makhtar, AM, Fakir, F. \& Chong, S.Y. (2016). Effect of Fines Content on Critical State Parameters of Sand Matrix Soils. AIP Conf Proc. 1755,060001-1-060001-8. 